\title{
THE EFFECT OF WAGES AND WORK EXPERIENCES ON THE COMMITMENT OF HUNGARIAN EMPLOYEES
}

\author{
Anita KOZÁK ${ }^{1}$, Zoltán KRAJCSÁK ${ }^{2}$ \\ ${ }^{1}$ Department of Economics, Eszterhazy Karoly University of Applied Sciences, Eger, Hungary \\ ${ }^{2}$ Department of Entrepreneurship and Human Resources, Budapest Business School, Budapest, Hungary \\ E-mails: ${ }^{1}$ kozak.anita@uni-eszterhazy.hu; ${ }^{2}$ krajcsak.zoltan@uni-bge.hu (correspondingauthor)
}

Received 24 April 2018; accepted 07 June 2018

\begin{abstract}
The purpose of this study is to find out whether there is a verifiable correlation between the individuals' employee commitment dimensions (affective, continuance, normative, professional and deliberate) and the personal characteristics of these employees. Our research was carried out among the employees of 56 organizations based in Hungary. Organizations were selected by snowball method. A total of 1731 questionnaires were processed, besides descriptive statistical methods we have used variance analysis. We have found significant correlations between the ages of employees and the level of affective, continuance, normative and professional commitment as well, by age-grouping and wage-grouping too. The results show that the first communication mode also has a significant impact on these four commitment dimensions, and all of the commitment dimensions had a higher level among employees who was enquired by the organization (the direction of the first communication is from the organization to the employee).
\end{abstract}

Keywords: human management, employee commitment, professional commitment, organizational commitment, deliberate commitment, wages, labor market.

JEL Classification: D23, J11, J62, O15.

\section{Introduction}

Workplace commitment is a popular research field in management for decades, and practicing managers and researchers also has been trying to answer what tools are the most relevant to increase employees' commitment levels to their workplaces. The exceptional attention is probably due to the fact that employee commitment has many positive advantages. Szabó (2016) points out the followings:

- there is a positive correlation between commitment and willingness to remain;

- committed employees clearly understand the goals of the organization and the steps it takes to achieve the goals;

- the absence of committed employees is less and take fewer sick leave;

- employee commitment is associated with factors that relevant to corporate success and business outcomes (e.g. higher productivity, lower recruitment costs).
Commitment-related corporate and scientific studies are getting increased attention, as more and more organizations are struggling with recruitment and labor retention difficulties because of the shortage of labor market. Such a solution is, for example, the creation of employee groups, segmenting employees and developing a motivational strategy based on common extrinsic and intrinsic motivational needs of each group. Retention management has become one of the key areas of human management, and organizations have been forced to use new methods and special motivators, in addition to proven incentives. For the selection and review of these techniques, it is important to evaluate employee commitment and to define employees' "commitment profiles". Such studies usually associate employee commitment with socio-demographic variables and various factors related to job satisfaction (see e.g. Yamao and Sekiguchi 2015, Huhtala and Feldt 2016). It is also true of scientific studies conducted in this subject, that initially

Copyright $\odot 2018$ The Authors. Published by VGTU Press.

This is an Open Access article distributed under the terms of the Creative Commons Attribution License (http://creativecommons.org/licenses/by/4.0/), which permits unrestricted use, distribution, and reproduction in any medium, provided the original author and source are credited.. 
revealed these relationships and explained the employees' behavior in the one-dimensional model of the organizational commitment, and it was later followed by two- and multi-dimensional commitment models.

In the model of employee commitment, the three-dimensional organizational commitment (Meyer and Allen 1984) is complemented by the factors of professional commitment and deliberate commitment, which are partly related to new variables less researched in domestic research so far.

The aim of this paper is to answer the question of whether certain variables, such as the way of recruiting and the wages how affect the certain dimensions of employee commitment. Based on the results, the motivation toolkit of the management can be more appropriately compared to the practice. Commitment dimensions can be supported by other tools, while the results also show that money is only partially supports the employees' commitment.

\section{Literature review}

Researchers have been actively involved in the topic of employees' commitment since the 1960s. According to Becker's (1960) Side-bet Theory, a committed behavior is a result when an employee recognizes the losses derived from leaving the organization, and maintains the committed behavior to avoid these disadvantages. Perception and judgment of losses are influenced by a number of personal and organizational factors. According to Parsons (1964) the employees' commitment and job attitudes are determined by their personalities and the interrelationship of organizational factors. On this basis, more and more empirical researches had been carried out in this subject. Their purpose was primarily to reveal the personal and organizational factors behind the committed behavior. The researches were essentially focused on the following areas:

- personal features (e.g. Ritzer and Trice 1969, Hrebiniak 1971, Hrebiniak and Alutto 1972);

- the nature of the work (e.g. Argyris 1964, Moore 1965, Grusky 1966, Thornton 1970, Hall and Schneider 1972);

- and the organizational factors (e.g. Hall and Schneider 1972, Buchanan 1974, Dubin et al. 1976).

In exploring personal characteristics, the researches have shown a correlation between the level of commitment and the gender, age, degree of education, and time spent in an organization. The results show that women, older workers, lower educated employees, and employees with a longer period of time in an organization are less likely to leave their workplaces. Regarding the nature of the work, researchers have found that job satisfaction, work diversity and the level of self-sufficiency correlate positively with commitment. Examining organizational factors has linked the commitment to the satisfaction with formal and informal groups, with participating in decision-making and targeting aims, and with the leadership style (Yousef 2017, Fu and Deshpande 2014, Chesnut and Burley 2015, Yahaya and Ebrahim 2016).

In addition to the personal characteristics, the nature of the work and the organizational factors, researchers had begun to explore the emotional dimensions of commitment, which they examined primarily through the levels of employees' organizational integrations. The integration into an organization was defined three levels:

- adaptation: the employee behaves in line with the organizational expectations, but cannot identify with organizational values and goals;

- identification: the employee is satisfied with his job and job responsibilities but does not seek to integrate deeper into the organizational culture;

- internalization: a complete involvement - the organization's objectives and values are recognized by the employee, and the integration of the job and workplace is fully realized (Smith et al. 1983).

O’Reilly and Chatman (1986) examined the relationships among the workplace behavior (the level of an employee wants to make a high perform and is willing to make extra efforts to his workplace), the three levels of organizational integration, and the likelihood of leaving the organization. According to their research, employees who are considered as an "identified" or an "internalized" are more likely to make extra efforts to their workplaces or have less chance of leaving the organization (it is worth mentioning that besides the turnover intention, the employees' workplace behavior also became into the focus in researches related to the organizational commitment). According to Kiss $(2013,35)$, the researchers interpreted and studied the commitment as follows: "The degree of identification and the involvement of an individual in relation to an organization, which defined by three factors:

1. strong beliefs and the acceptance of goals and values of the organization;

2. a willingness to make important efforts for the organization;

3. expressed desire to maintain membership of the organization in a long term."

The employees' extra efforts in the theory of O'Reilly and Chatman (1986) (the second point of the above), are manifesting in fact in the organizational citizenship behavior (OCB). Organizational citizenship behavior includes those activities that exceed the basic requirements of the job and are useful to the organization (Lambert 2006). OCB in this approach -is considered to be a manifestation of organizational commitment, and in any case presupposes an emotional attachment (to employees' profession and / or to his organization). Commitment studies in this early 
period were therefore especially based on the „emotional identification" aspect, and later were linked to several variables, for example:

- to some of factors of job satisfaction (Mowday et al. 1982, Gerhart and Judge 1991);

- to extrinsic and intrinsic motivation (Caldwell et al. 1990, Mathieu and Zajac 1990);

- to work ethics, career opportunities, the role of occupation and job in employees' career, and the union's commitment (Morrow 1983).

With regard to employee commitment, researchers later have realized that attachment to the organization can not only be accomplished on an emotional basis, but can be influenced by other factors and circumstances as well. This theory relates to Allen and Meyer (1990) who created the three-component model of commitment:

1. Affective commitment: the employee is emotionally attached to the organization or his direct colleagues, identifies with the organizational goals and values the employee is therefore ties to the organization because he "wants it".

2. Continuance commitment: the employee binds to the organization as this is the best for him. Continuance commitment implies that if there was a more profitable alternative for an employee, he would leave the organization - the individual is therefore bound to his workplace because it is "worth".

3. Normative commitment: It is a moral duty of the employee to maintain his organization membership. The motivation comes from the conscience as an employee wants to acknowledge that the organization invested in his workforce, but the employee's prior work experiences and culture can also be an influencing factor - the employee is therefore bound to the organization because he feels "his duty" (Meyer and Allen 1984).

All of these together define the employees' commitment profiles. The relative strengths of dimensions in relation to each other define the employees' attitudes and behaviors in the workplace.

It was found that the three components of the organizational commitment are related to each other, but these can be distinguished. All the three dimensions negatively correlate with the turnover intention, but affective commitment has the strongest and most favorable correlation with factors relevant to the organization (participation, performance and organizational citizenship behavior) and to the employees (e.g. stress-level and work-family balance). Normative commitment is less strongly related to these factors, and the continuance commitment does not, or negatively correlates with these (Meyer et al. 2002). Therefore affective commitment can be regarded as a basis of the most valuable organizational behavior, which is an emotional relationship, serving benefits to the organization (Wasti 2003).
In addition to the three dimensions of commitment, the concept of professional commitment also appeared in the literature. Professional commitment can be described as a behavior in which an employee is able to identify himself with the profession he has, adopts professional goals and ethical standards (Mueller et al. 1992). In parallel with this interpretation, the concept of career commitment was characterized by a sense of identity, conviction, development and strong participation in active career - in other words, the employee's commitment to one of his career goals (Colarelli and Bishop 1990). However, professional commitment does not strengthen organizational commitment, yet there are some behavioral implications that are indirectly useful to organizations. For example, it reduces the turnover intention and the high level of professional commitment helps the tasks and purposes to be accomplished (Chang 1999).

In recent years, researches of employee commitment sought to find the answer to what managerial and organizational factors are related to its scale. Researchers are primarily aimed at exploring good practices that can contribute to increasing employee commitment.

Gilbert et al. (2011) and Alfes et al. (2013) emphasize the importance of human resource management (HRM) practices, based on their findings, the measures of the HRM and through them the behavior of the line leaders - greatly influences employees' commitment. Results by Demirtas and Akdogan (2015) and Ashikali and Groeneveld (2015) are also relevant to the understanding the behavior of line leaders.

In exploring factors affecting the entire organization, other variables also have a significant role on commitment, such as caring climate, perceived organizational support (POS), internal communication, and corporate social responsibility (CSR). Erdogan et al. (2015), Kurtessis et al. (2015) and Vardaman et al. (2016) also point out that there is a relationship between perceived organizational support (POS) and employees' commitment, i.e. leadership, employee-organization context, human resource practices and working conditions are factors that, through targeted development, employers can contribute to increasing employees' commitment.

Therefore, it can be seen that recent researches of commitment have been focused on the internal factors of the organizations, and the researchers examined the job attitudes as a function of the organizational behavior. In our view, it is worth noting that factors affecting the internal, but also the external, especially the labor market, should be included in the test models. Labor market trends can greatly influence employees' behaviors (Krajcsák 2014), and there had been introduced the notion of deliberate commitment with testing its relevance of the five dimensional employee commitment model. Deliberate commitment is an attitude of employees without any real alternatives and chances in the 
labor market, in which an employee seems to be more committed than he really is, so this attitude results in a cunning behavior towards the colleagues and executives. Deliberate commitment is more commonly observed in a recessionaffected economic environment where the labor market is more seriously affected by the high unemployment rate. However, over the past few years, despite the difficulties of employability of the unskilled people, the shortage has emerged of the high-skilled, talented workers.

The labor market of CEE10 countries is negatively affected by the proportion of emigrants and immigrants. Darvas and Raposo (2018) reports the number of the emigrant and immigrant employees per country for 2010 and 2015. The data show that the number of emigrating workers has increased dramatically in all EU member states in the CEE region - particularly in Poland, Slovenia and Slovakia - and this is not proportional to the size of the immigrant labor force. This is supported by data of Eurostat (2017), which shows that there is a steady increase in mobility among the countries. In 2016, 3 million employees were registered from an EU member state to another EU country. Eurostat (2018) does not contain data for employees who return to their homeland after some time - some years of foreign employment - but labor market surveys affecting this issue in each country. According to several comparative studies, Hárs and Simon (2016) found that there is a significant part of the workers emigrating from Central and Eastern Europe are deliberately planning to return, and the rate of returnees gradually increases after the crisis.

Due to current labor market trends, organizations need to broaden the range of their recruitment methods and account for a new group of employees, with the workers who have work experience abroad. The question then arises whether there is a demonstrable link between the direct recruitment techniques employed by the organizations and the different dimensions of work experience abroad and the different dimensions of employees' commitment based on direct contact with the employees.

In recent years, researches of employee commitment sought to find the answer to what managerial and organizational factors are related to its scale. Researchers are primarily aimed at exploring good practices that can contribute to increasing employee commitment.

Gilbert et al. (2011) and Alfes et al. (2013) emphasize the importance of human resource management (HRM) practices, based on their findings, the measures of the HRM and through them the behavior of the line leaders - greatly influences employees' commitment. Results by Demirtas and Akdogan (2015) and Ashikali and Groeneveld (2015) are also relevant to the understanding the behavior of line leaders.

In exploring factors affecting the entire organization, other variables also have a significant role on commitment, such as caring climate, perceived organizational support (POS), internal communication, and corporate social responsibility (CSR). Erdogan et al. (2015), Kurtessis et al. (2015) and Vardaman et al. (2016) also point out that there is a relationship between perceived organizational support (POS) and employees' commitment, i.e. leadership, employee-organization context, human resource practices and working conditions are factors that, through targeted development, employers can contribute to increasing employees' commitment.

Therefore, it can be seen that recent researches of commitment have been focused on the internal factors of the organizations, and the researchers examined the job attitudes as a function of the organizational behavior. In our view, it is worth noting that factors affecting the internal, but also the external, especially the labor market, should be included in the test models. Labor market trends can greatly influence employees' behaviors (Krajcsák 2014), and there had been introduced the notion of deliberate commitment with testing its relevance of the five dimensional employee commitment model. Deliberate commitment is an attitude of employees without any real alternatives and chances in the labor market, in which an employee seems to be more committed than he really is, so this attitude results in a cunning behavior towards the colleagues and executives. Deliberate commitment is more commonly observed in a recessionaffected economic environment where the labor market is more seriously affected by the high unemployment rate. However, over the past few years, despite the difficulties of employability of the unskilled people, the shortage has emerged of the high-skilled, talented workers.

The labor market of CEE10 countries is negatively affected by the proportion of emigrants and immigrants. Darvas and Raposo (2018) reports the number of the emigrant and immigrant employees per country for 2010 and 2015. The data show that the number of emigrating workers has increased dramatically in all EU member states in the CEE region - particularly in Poland, Slovenia and Slovakia -, and this is not proportional to the size of the immigrant labor force. This is supported by data of Eurostat (2017), which shows that there is a steady increase in mobility among the countries. In 2016, 3 million employees were registered from an EU member state to another EU country. Eurostat (2018) does not contain data for employees who return to their homeland after some time - some years of foreign employment - but labor market surveys affecting this issue in each country. According to several comparative studies, Hárs and Simon (2016) found that there is a significant part of the workers emigrating from Central and Eastern Europe are deliberately planning to return, and the rate of returnees gradually increases after the crisis.

Due to current labor market trends, organizations need to broaden the range of their recruitment methods and 
account for a new group of employees, with the workers who have work experience abroad. The question then arises whether there is a demonstrable link between the direct recruitment techniques employed by the organizations and the different dimensions of work experience abroad and the different dimensions of employees' commitment based on direct contact with the employees.

Our focus was on the five dimensions of employee commitment (affective, continuance, normative, professional, and deliberate) and we were basically looking for the relationships between the mean values of each commitment dimension and certain features of the respondent - including the existence or absence of work experience acquired abroad and the type of the first time communication between the employee and organization. Our hypotheses were set up based on the literature processing and our preliminary research results.

H1: The age of employees is related to their affective, normative and professional commitment as well.

According to the results of Meyer and Allen (1984), normative and affective commitment increased by the age. According to Miner (1993), there is a higher level of professional commitment in the older age group.

H2: There is a positive correlation between employees' wages and the levels of affective, normative, continuance and professional commitment.

By exploring the degree of the wages and the relationship between commitment, researchers (Hrebiniak 1971; Hrebiniak and Alutto 1972) have examined it since the early of 1970's, and later with the spreading of the three-component model of commitment, each commitment dimension have been studied individually according to the employees' satisfactions about their wages and compensations for their jobs. Based on the results, there are positive correlations between the variables pairwise (regarding affective commitment see Rizqi and Saptoto 2015, regarding continuance commitment see Mosadeghrad and Ferdosi 2013, and regarding normative commitment see Lipinskiene 2008). The link between professional commitment and the rate of the payment had already been studied by researchers (e.g. Hall et al. 2005, Wang et al. 2010), and concluded that the higher the level of wages is, the stronger the professional commitment.

H3: There is no correlation between the foreign job experience and the level of employee commitment.

In view of the labor market situation in Hungary (the increasing number of emigrated employees and the number of migrants coming back from there), we have found it interesting to examine the average levels of the employee commitment dimensions according to whether the employee had previously worked abroad or not. Since we had not found a test result showing a link between work experiences in abroad and the levels of any dimensions of employee commitment (nor a research that would have dealt with this question), therefore, we have not assumed any correlation with the group-forming criterion.

$\mathrm{H} 4$ : There is no any connection between the method of the first contact with the organization and the average levels of the dimensions of employee commitment. Potential workers my contact with employers via applying for an advertisement, by recommendation or by direct contact with the organization. Due to the lack of skilled workforce, in addition to advertising, more and more organizations operate a recognition system and are forced to use recruiting techniques based on personal inquiries. The latter also functions as a sort of pre-selection filter that predicts the applicant's skills on the position, and the candidate has a psychological relevance for the selected status as well. However, since we did not find any research findings suggesting a link between the method of contacting the organization and the attitudes of commitment, and the commitment was influenced by personal and organizational factors based on the literature, so there was no any presumption of correlation between the two variables.

On the one hand, we had not found any result that would referred to it, and on the other hand, attitudes of employee commitment are influenced by personal and organizational factors based on the literature, therefore we do not assume any correlation between the variables.

\section{Methodology}

The hypotheses were tested among 56 organizations that are based in Northern Hungary and in the North Great Plain region in Hungary. Organizations were included in the sample whether they were available, and we have applied the snowball method to find them. When selecting organizations, it was a matter of being a profit-making venture or of small, medium and large companies in the sample as well. Of the 56 organizations, 23 are small enterprises, 17 are middle companies and 16 are large organizations, which are classified by the number of employees and annual turnover. Data collection was took from October 2017 to December 2017 via printed and electronically questionnaires. Respondents evaluated items related to each commitment dimension from 1 to 7 (1: not at all, 7: fully). The items related to the affective, continuance and normative commitment were based on Meyer and Allen's (1984) organizational commitment model, items of professional commitment were based on a Aranya et al. (1981) and Rothwell and Arnold (2007), and items of deliberate commitment were based on Krajcsák (2014). The sample includes 1731 responds of employees, which data were evaluated by using the SPSS statistical program.

Prior to conducting our tests, the Cronbach alpha indicator was tested in each employee commitment dimension (see Table 1). 
Table 1. Cronbach alphas in each commitment dimension

\begin{tabular}{|l|c|}
\hline \multicolumn{1}{|c|}{ Commitment dimensions } & Cronbach alpha \\
\hline Affective & 0,911 \\
\hline Continuance & 0,777 \\
\hline Normative & 0,852 \\
\hline Professional & 0,909 \\
\hline Deliberate & 0,826 \\
\hline
\end{tabular}

Source: own research data.

All alphas were above 0.7 in all the five commitment dimensions, so data was considered reliable for further testing.

All dimensions were analyzed by $5-5$ items with averaging the answers in each group and creating new variables (affective, continuance, normative, professional, and deliberate). The new variables are able to characterize commitment dimensions after averaging the 5 evaluated items in each dimension. For the analysis we have applied the descriptive statistics (frequencies and means), and we have used cross-tabulation Kruskal-Wallis and Mann-Whitney test to perform our detailed analyzes. The results of the statistical tests were considered significant at $\mathrm{p}<0.05$.

Regarding the gender, $46.4 \%$ were women and $53.6 \%$ were men of the sample. $14.6 \%$ of them were born between 1946 and 1964 (Baby Boomers), 41.4\% between 1965 and 1979 (Generation X), 38.4\% between 1980 and 1995 (Generation Y), and 5.6\% were born after 1995 (Generation Z). In terms of qualification, $17.8 \%$ have primary, $61.8 \%$ have secondary and $20.4 \%$ have higher education. Compared to similar jobs, $9.4 \%$ of the respondents earn above the average, $73.2 \%$ of them earn the average, and $17.4 \%$ of them are below of the average in compensation. $13.7 \%$ of the respondents work in manager positions, with a $86.3 \%$ of them subordinate. As to the nature of their employment, $88.7 \%$ are employed in full time, $7.1 \%$ in part-time and $4.2 \%$ employed

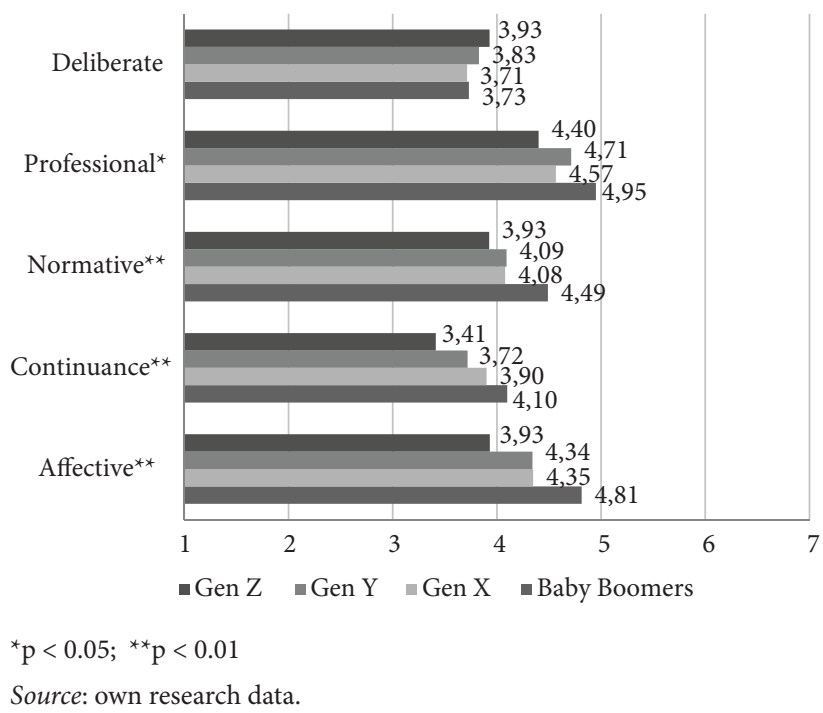

Figure 1. Commitments by generation cohorts $(\mathrm{N}=1731)$ in a contractual relationship. $20.6 \%$ of respondents were in the organization less than a year, $23.8 \%$ more than 1 year, and $55.5 \%$ of the employees have been working for more than 3 years at the same employer. Surprisingly, $16.9 \%$ of the sample has already been worked abroad. $21.1 \%$ of the employees with foreign work experiences had less than 3 months, $30.8 \%$ of them had minimum 3 and maximum 12 months, $28.7 \%$ of the employees have worked between 1 and 3 years, and $19.7 \%$ of them have more than 3 years of working experiences of abroad. As regards the establishment of their employment relationship, only $35.1 \%$ of them applied for job advertisement, $20.1 \%$ stated that they had been directly contacted by the organization and almost the half of the respondents (44.2\%) were recommended to the organization.

\section{Results}

In terms of the average levels of each commitment dimension, the professional commitment represents the highest (MEAN=4.66; $\mathrm{SD}=1,49)$ value followed by the affective (MEAN=4.39; $\mathrm{SD}=1.51)$, normative $(\mathrm{MEAN}=4.13$; $\mathrm{SD}=1.45$ ), continuance (MEAN=3.83; $\mathrm{SD}=1,39)$ and the deliberate commitment (MEAN=3.77; $\mathrm{SD}=1.39)$. Given that affective commitment is considered the most valuable in the three-component model, and deliberate commitment implies the least real workplace affiliation, these results are favorable for the organizations. The high level of professional commitment makes it difficult to understand the nature of employees' commitment, as is has been mentioned above; there is an opposing relationship between professional commitment and loyalty to the organization. Therefore it should be important to examine in details the components of professional and affective commitment. According to Alvesson (2004) and Scarbrough (1999) highly skilled employees tend to feel more committed to their profession than their organization. We have found a significant difference among the levels of education graduates (at $\mathrm{p}=0.00$ for professional commitment and at $\mathrm{p}=0.01$ for affective commitment). However, this did not support the conclusions of previous researches, as our results show that the higher the education level of an employee, the more he feels committed to both his profession and his workplace. Our data draws attention to the fact that during evaluating the results it has to take into account the labor market conditions in the tested area. Namely, in labor markets without any labor shortage - because of the limited scope - there is a less likelihood about employees with high levels of affective and professional commitment would give up their existing workplace. The results of our age-based detail analyzes related to our first hypothesis are shown in Figure 1.

Among the commitment dimensions, variance analysis showed significant differences in affective, continuance, normative and professional commitment along the 
group-forming criteria. The mean value of all four dimensions is increasing with the age, which means that age really influences the types of commitment presented above. Therefore the studies substantiated our premise, but failed to justify the test result of Meyer and Allen (1984) about the age is not related to the continuance dimension. Our result is probably due to the fact that, with the age - specially the employees of the Baby Boomers - the possibility of changing job initiated by an employee is reduced.

It should be noted that other factors can play a role in the impact of the age on employee commitment. Such variables are, for example, the wage, which is growing with the age, the totality of goods at work, the existence of organizational and work-related routines, which act as intermediary variables in this relationship.

The deliberate commitment has the highest level among the career starters who feel compelled to demonstrate their ability to work in the hope of further employment and their professional development.

Our second hypothesis was related to the level of employees' wages, and the results are illustrated in Figure 2.

The rate of the wages is related to four of the five commitment dimensions (affective, continuance, normative and professional) - thus the results supported our preliminary assumption and the conclusions of previous researches as well. The most conspicuous difference relates to the affective commitment, where a nearly two-point difference is observed with respect to the levels given by groups of average and above average wages. This suggests that, due to the relationship between wage levels in Hungary and the cost of living, money is a very powerful motivator among the majority of employees.

Deliberate commitment - based on our results - is independent of the level of earnings, as it has the highest levels among the career starters with the lowest wages, and it is decreasing while the levels of satisfaction with the wages are increasing.

Our third and fourth hypotheses have linked the commitment dimensions with variables that were not in the focus of commitment researches. The average levels of the commitment dimensions are shown in Figure 3 depending on the foreign work experiences, while Figure 4 shows the results of how the respondent contacted at first with his current organization.

Employees with a foreign work experience show lower average levels of commitment in the affective, continuance, normative, professional dimensions, than employees without any working abroad experiences. Variance analysis has shown significant differences among the affective, continuance, and deliberate commitment dimensions along the group formation criteria. According to the findings of labor market researches, the Hungarian CEE10 countries employees are most likely to work abroad due to the higher

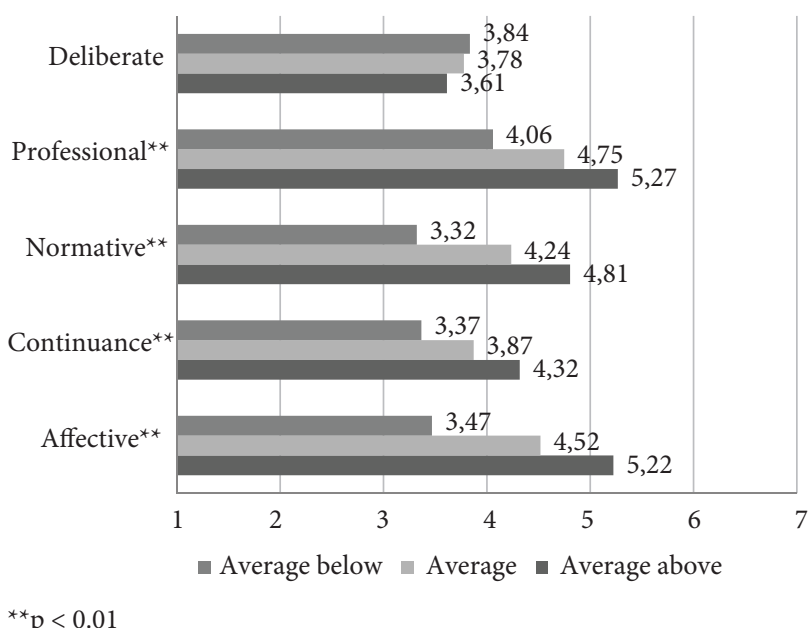

${ }^{* *} \mathrm{p}<0.01$

Source: own research data.

Figure 2. Commitments by wage groups $(\mathrm{N}=1731)$

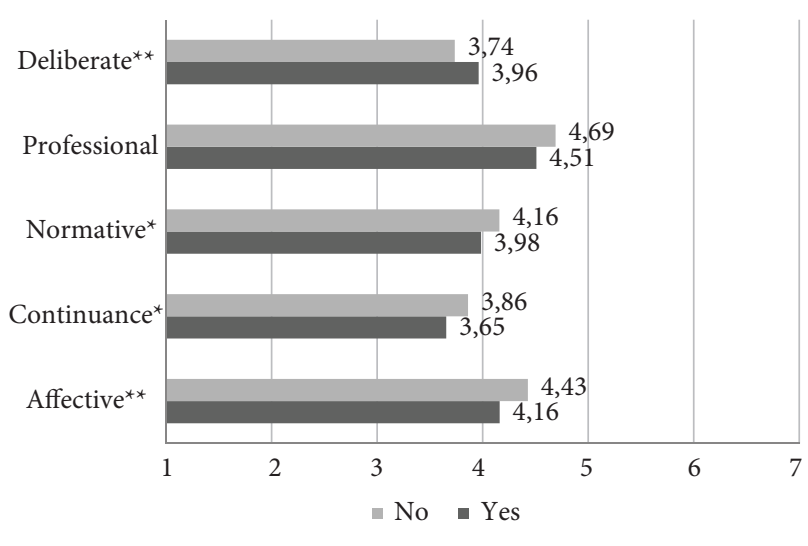

${ }^{*} \mathrm{p}<0.05 ;{ }^{* *} \mathrm{p}<0.01$

Source: own research data.

Figure 3. Commitments whether the employee had foreign work experience $(\mathrm{N}=1731)$

wage opportunities, a secure job, better working conditions and language learning. In the background of the results, we assumed that it may be that these experiences have less power to strengthen employee commitment in organizations that offer lower salaries for employees and can give them worse working conditions in North-Hungary as an area with lower welfare and economic indicators. Therefore we have examined the relationships between the satisfaction of wages and the foreign work experiences, but the results of the cross-examination have not shown any correlation between the two variables. Detailed analyzes were carried out with 28 items in our workplace satisfaction questionnaire in order to justify the lower level of the domestic employees' commitment which is probably caused by the worse working conditions. Surprisingly, there was also no significant difference in the variance analysis of a single factor of satisfaction with the group workout of foreign work experiences. Our results cannot therefore be explained by 
the fact that better working conditions and higher wages paid abroad are those that weaken the employees' commitment to the organizations in Hungary. In the background of this phenomenon, it may well be that the experience gained abroad can fundamentally change the attitudes of the employees, and in the future, they may be less able to associate with their (domestic) workplaces. Taking into account the labor market trends in the EU, organizations must be prepared to weaken employees' commitment, which cannot be improved by raising wages and better working conditions. Therefore there is a need to revise the motivation systems, and more emphasis should be placed on non-material incentives in the future.

Our research has showed significant differences between the four commitment dimensions (affective, continuance, normative, professional) along the group-forming aspect of the employees' first contact method with the current organization. Our first thought was that highly educated professionals are those who were directly looking for organizations as to be their new workplaces, and this could explain the differences as they were more committed to their workplaces. Therefore cross-examination was conducted to examine the relation between the first contact method and the variables of the level of education, but based on the results; our assumption had not been justified, as $17.82 \%$ had basic, $58.91 \%$ had secondary and only $23.27 \%$ had a higher qualification among the employees who made their employment through a direct inquiry derived from the organization. All these implies that not only the organizational and individual characteristics are taken into account in accounting for factors influencing employees' commitment, but also the recruitment and selection processes may be decisive. Therefore, organizations, with the addition of new employees, should also place more emphasis on their

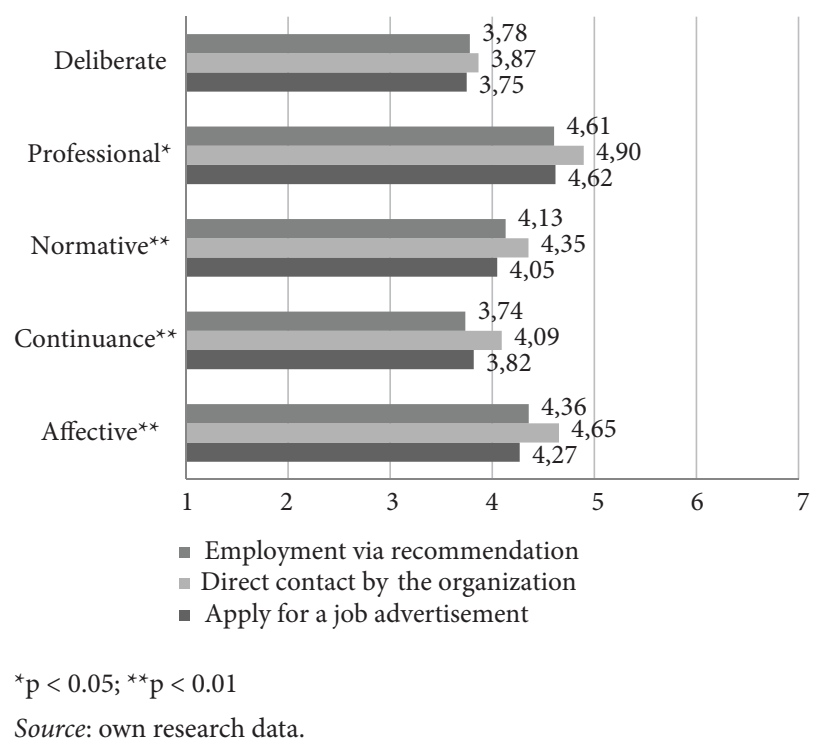

Figure 4. Commitments by the method of the first contact between the employee and organization $(\mathrm{N}=1731)$ personnel procurement procedures in order to retain the workforce. According to our results, the recruitment techniques based on personal search can enhance employee commitment, and the basis for later research can be the examination of experiences during the selection process.

\section{Conclusions}

Our results have largely been supported by conclusions of previous researches in this topic. In terms of the age, we have found that the average levels of affective, continuance, normative and professional commitment dimensions are increasing by the age and the same tendency can be observed for the four commitment dimensions in terms of the wages.

In our research, commitment dimensions were also linked to two variables which have not yet studied widely. In Hungary CEE10 countries, following the economic crisis, the number of people working abroad has increased dramatically, and in the last few years the rate of workers returned home and employed at a domestic organization also has been started to increase. According to our results, it would be worthwhile to examine deeper the relationship between the employee commitment and the foreign work experiences in a larger and international sample, since the commitment attitude varies depending on the cross-border working experiences.

The labor shortage makes challenges for human managers with regard to the recruitment techniques. More and more organizations are forced to use new techniques and solutions in recruitment, such as application systems for searching employees by recommendation or use direct contacting. The relationship between the method of contacting the prospective employee (admission by recommendation, application for a job advertisement, direct contact from the organization to the employee) and commitment was not assumed widely so far, since, according to the literature, the level of the commitment to the workplace is influenced by personal and organizational factors as well. However, according to our empirical research, the average levels in almost each commitment dimension (affective, continuance, normative, professional dimensions) were higher among employees who were contacted by the organizations directly.

The results are valid in the Hungarian culture, and in the Hungarian labor market characteristics and trends. Further studies should be carried out in other national cultures to influence the impact of wages, work experiences and other organizational variables on the five dimensions of employee commitment.

\section{Acknowledgement}

The research was supported by the UNKP-17-14 New National Excellence Program of the Ministry of Human Capacities, Hungary. 


\section{References}

Ali I, Rehman KU, Ali SI, Yousaf J, Zia M (2010) Corporate social responsibility influences, employee commitment and organizational performance. African Journal of Business Management 4 (12): 2796-2801.

Alfes K, Shantz A, Truss C, Soane E (2013) The link between perceived human resource management practices, engagement and employee behaviour: a moderated mediation model. The International Journal of Human Resource Management 24 (2): 330-351. https://doi.org/10.1080/09585192.2012.679950

Allen NJ, Meyer JP (1990) The measurement and antecedents of affective, continuance and normative commitment to the organization. Journal of Occupational Psychology 63 (1): 1-18. https://doi.org/10.1111/j.2044-8325.1990.tb00506.x

Alvesson M (2004) Knowledge work and knowledge-intensive firms. Oxford: Oxford University Press.

Aranya N, Pollock J, Amernic J (1981) An examination of professional commitment in public accounting. Accounting, Organizations and Society 6 (4): 271-280. https://doi. org/10.1016/0361-3682(81)90007-6

Argyris C (1964) Integrating the individual and the organization. New York: John Wiley.

Ashikali G, Groeneveld S (2015) Diversity management in public organizations and its effect on employees' affective commitment: the role of transformational leadership and the inclusiveness of the organizational culture. Review of Public Personnel Administration 35 (2): 146-168. https://doi. org/10.1177/0734371X13511088

Becker HS (1960) Notes on the concept of commitment. American Journal of Sociology 66 (1): 40-53. https://doi. org/10.1086/222820

Buchanan B (1974) Building organizational commitment: the socialization of managers in work organizations. Administrative Science Quarterly 19 (4): 533-546. https://doi. org/10.2307/2391809

Caldwell DF, Chatman JA, O'Reilly CA (1990) Building organizational commitment: a multi-firm study. Journal of Occupational Psychology 63 (3): 245-261. https://doi. org/10.1111/j.2044-8325.1990.tb00525.x

Chang E (1999) Career commitment as a complex moderator of organizational commitment and turnover intention. Human Relations 52 (10): 1257-1278. https://doi. org/10.1177/001872679905201002

Chesnut SR, Burley H (2015) Self-efficacy as a predictor of commitment to the teaching profession: a meta-analysis. Educational Research Review 15: 1-16. https://doi.org/10.1016/j. edurev.2015.02.001

Colarelli SM, Bishop RC (1990) Career commitment: functions, correlates and management. Group and Organization Studies 15 (2): 1580-178. https://doi.org/10.1177/105960119001500203

Darvas Zs, Raposo I (2018): People on the move: migration and mobility on the European Union. Bruegel Blueprint Series, Volume XXVIII, Bruegel.

Demirtas O, Akdogan A (2015) The effect of ethical leadership behavior on ethical climate, turnover intention, and affective commitment. Journal of Business Ethics 130 (1): 59-67. https:// doi.org/10.1007/s10551-014-2196-6
Dubin R, Hedley R, Taveggia T (1976) Attachment to work. In: Dubin R (Eds) Handbook of work, organization, and sociology. Skokie: Rand McNally, 281-341.

Erdogan B, Bauer T, Taylor S (2015) Management commitment to the ecological environment and employees: Implications for employee attitudes and citizenship behaviors. Human Relations 68 (11): 1669-1691. https://doi.org/10.1177/0018726714565723

Gerhart BA, Judge TA (1991) Measures of new constructs or old ones? The case of organizational commitment and job satisfaction - CAHRS Working Paper. Ithaca, NY: Cornell University, School of Industrial and Labor Relations, Center for Advanced Human Resource Studies.

Eurostat (2018) European Comisson: Commission report: Employment and social situation in the EU continues to improve (Brussels, 12 February 2018) http://europa.eu/rapid/pressrelease_IP-18-721_en.htm

Eurostat (2017) Migration and migrant population statistics http:// ec.europa.eu/eurostat/statistics-explained/index.php/Migration_and_migrant_population_statistics

Fu W, Deshpande SP (2014) The impact of caring climate, job satisfaction, and organizational commitment on job performance of employees in a China's insurance company. Journal of Business Ethics 124 (2): 339-349. https://doi.org/10.1007/ s10551-013-1876-y

Gilbert C, Winne S, Sels L (2011) The influence of line managers and HR department on employees' affective commitment. The International Journal of Human Resource Management 22 (8): 1618-1631. https://doi.org/10.1080/09585192.2011.565646

Grusky O (1966) Career mobility and organizational commitment. Administrative Science Quarterly 10 (4): 488-503. https://doi. org/10.2307/2391572

Hall DT, Schneider B (1972) Correlates of organizational identification as a function of career pattern and organizational type. Administrative Science Quarterly 17 (3): 340-350. https://doi. org/10.2307/2392147

Hall M, Smith D, Langfield-Smith K (2005) Accountants' commitment to their profession: multiple dimensions of professional commitment and opportunities for future research. Behavioral Research in Accounting 17 (1): 89-109. https://doi.org/10.2308/ bria.2005.17.1.89

Hárs Á, Simon D (2016) A külföldi munkavállalás és a munkaerőhiány”. In: Munkaerőpiaci tükör, MTA Közgazdaságés Regionális Tudományi Kutatóközpont Közgazdaságtudományi Intézet. Budapest, 94-108.

Hrebiniak LG, Alutto JA (1972) Personal and role-related factors in the development of organizational commitment. Administrative Science Quarterly 17 (4): 555-573. https://doi. org/10.2307/2393833

Hrebiniak LG (1971) A multivariate analysis of professional and organizational commitment orientations among teachers and nurses. Doctoral Dissertation, State University of New York at Buffalo.

Huhtala M, Feldt T (2016) The path from ethical organisational culture to employee commitment: mediating roles of value congruence and work engagement. Scandinavian Journal of Work and Organizational Psychology 1 (1): 1-14. 
Kiss Cs (2013) A szervezeti elkötelezettség és a munka-család konfliktus összefüggései az ügyfélszolgálati munkában [Organizational Commitment and Work-Family Conflict in Customer Service Centres]. PhD Thesis, Corvinus University of Budapest.

Krajcsák Z (2014) Alkalmazotti elkötelezettségi profilok egyes speciális munkaválallói csoportokban [Workplace commitment profiles in special groups of employees]. PhD Thesis, Budapest University of Technology and Economics.

Kurtessis J, Eisenberger R, Fod M, Buffardi L, Stewart K, Adis C (2015) Perceived organizational support: a meta-analytic evaluation of organizational support theory. Journal of Management 20 (10): 1-31.

Lambert SJ (2006) Both art and science: employing organizational documentation in workplace-based research. In: Pitt-Catsouphes M, Kossek EE, Sweet S (Eds) The work and family handbook: multi-disciplinary perspectives, methods, and approaches. Mahwah, New Jersey: Lawrence Erlbaum Associates, 503-525.

Lipinskiene D (2008) The examination of relationship between organizational commitment and job satisfaction of employees. Ekonomika ir vadyba: aktualijos ir perspektyvos 4 (13) 282-289.

Mathieu JE, Zajac DM (1990) A review and meta-analysis of the antecedents, correlates, and consequences of organizational commitment. Psychological Bulletin 108 (2): 171-194. https:// doi.org/10.1037/0033-2909.108.2.171

Meyer JP, Allen NJ (1984) Testing the "side-bet theory" of organizational commitment: some methodological considerations. Journal of Applied Psychology 69 (3): 372-378. https://doi. org/10.1037/0021-9010.69.3.372

Meyer JP, Stanley DJ, Herscovitch L, Topolnytsky L (2002) Affective, continuance, and normative commitment to the organization: a meta - analysis of antecedents, correlates and consequensces. Journal of Vocational Behavior 61 (1): 20-52. https://doi. org/10.1006/jvbe.2001.1842

Miner J (1993) Role motivation theories. Routledge: London. https://doi.org/10.4324/9780203293287

Moore WE (1965) The impact of industry. Englewood Cliffs, NJ: Prentice-Hall.

Morrow PC (1983) Concept redundancy in organizational research: the case of work commitment. The Academy of Management Review 8 (3): 486-500. https://doi.org/10.5465/ amr.1983.4284606

Mosadeghrad M, Ferdosi M (2013) Leadership, job satisfaction and organizational commitment in healthcare sector: proposing and testing a model. Mater Sociomed 25 (2): 121-126. https:// doi.org/10.5455/msm.2013.25.121-126

Mowday RT, Porter LW, Steers RM (1982) Employee-organizational linkages. New York: Academic Press.

Mueller CW, Wallace JE, Price JL (1992) Employee commitment: resolving some issues. Work and Occupations 19 (3): 211-236. https://doi.org/10.1177/0730888492019003001
O’Reilly CA, Chatman J (1986) Organizational commitment and psychological attachment: the effects of compliance, identification, and internalization on prosocial behavior. Journal of Applied Psychology 71 (3): 492-499. https://doi. org/10.1037/0021-9010.71.3.492

Parsons T (1964) The Social Systems. New York: Free Press.

Ritzer G, Trice HM (1969) An empirical study of Howard Becker's side-bet theory. Social Forces 47: 475-479. https://doi. org/10.2307/2574537

Rizqi A, Saptoto R (2015) The effects of pay satisfaction and affective commitment on turnover intention. International Journal of Research Studies in Psychology 4 (2): 57-70.

Rothwell A, Arnold J (2007) Self-perceived employability: development and validation of a scale. Personnel Review 36 (1): 23-41. https://doi.org/10.1108/00483480710716704

Scarbrough H (1999) Knowledge as work: conflicts in the management of knowledge workers. Technology and Strategic Management 11 (1): 5-16. https://doi.org/10.1080/095373299107546

Smith CA, Organ D, Near J (1983) Organizational citizenship behavior: its nature and antecedents. Journal of Applied Psychology 68 (4): 653-663. https://doi.org/10.1037/0021-9010.68.4.653

Szabó A (2016) A munkavállalói elkötelezettség növelésének hatása és lehetőségei [Impact and possibilities of increasing employee commitment]. Opus et Educatio 3 (4): 439-450. https://doi. org/10.3311/ope.41

Thornton R (1970) Organizational involvement and commitment to organization and profession. Administrative Science Quarterly 15 (4): 417-427. https://doi.org/10.2307/2391333

Vardaman J, Allen D, Otondo R, Hancock J, Shore L, Rogers B (2016) Social comparisons and organizational support: implications for commitment and retention. Human Relations 69 (7): 1483-1505. https://doi.org/10.1177/0018726715619687

Wang K, Chou C, Huang J (2010) A study of work values, professional commitment, turnover intention and related factors among clinical nurses. Hu Li Za Zhi 57 (1): 22-34.

Wasti S (2003) Organizational commitment, turnover intentions and the influence of cultural values. Journal of Occupational and Organizational Psychology 76 (3): 303-321. https://doi. org/10.1348/096317903769647193

Yahaya R, Ebrahim F (2016) Leadership styles and organizational commitment: literature review. Journal of Management Development 35 (2): 190-216. https://doi.org/10.1108/JMD01-2015-0004

Yamao S, Sekiguchi T (2015) Employee commitment to corporate globalization: the role of English language proficiency and human resource practices. Journal of World Business 50 (1): 168-179. https://doi.org/10.1016/j.jwb.2014.03.001

Yousef DA (2017) Organizational commitment, job satisfaction and attitudes toward organizational change: a study in the local government. International Journal of Public Administration 40 (1): 77-88. https://doi.org/10.1080/01900692.2015.1072217 
APPENDIX

Correlation values among the affective commitment items

\begin{tabular}{|l|l|l|l|l|l|}
\hline & Question1 & Question2 & Question3 & Question4 & Question5 \\
\hline Question1 & &, $744\left(^{* *}\right)$ &, $686\left(^{* *}\right)$ &, $649\left(^{(*}\right)$ &, $615\left(^{* *}\right)$ \\
\hline Question2 & & &, $699\left(^{* *}\right)$ &, $631\left(^{* *}\right)$ &, $637\left(^{(*}\right)$ \\
\hline Question3 & & & &, $697\left(^{* *}\right)$ &, $686\left(^{* *}\right)$ \\
\hline Question4 & & & & &, $696\left(^{* *}\right)$ \\
\hline Question5 & & & & & \\
\hline
\end{tabular}

** Correlation is significant at the 0.01 level (2-tailed).

Correlation values among the continuance commitment items

\begin{tabular}{|l|l|l|l|l|l|}
\hline & Question1 & Question2 & Question3 & Question4 & Question5 \\
\hline Question1 & &, $279\left(^{* *}\right)$ &, $186\left(^{* *}\right)$ &, $\left.207^{* *}\right)$ &, $266\left(^{* *}\right)$ \\
\hline Question2 & &, $543\left({ }^{* *}\right)$ &, $475\left(^{* *}\right)$ &, $441(* *)$ \\
\hline Question3 & & & &, $682(* *)$ &, $493(* *)$ \\
\hline Question4 & & & & &, $561(* *)$ \\
\hline Question5 & & & & & \\
\hline
\end{tabular}

** Correlation is significant at the 0.01 level (2-tailed).

Correlation values among the normative commitment items

\begin{tabular}{|l|l|l|l|l|l|}
\hline & Question1 & Question2 & Question3 & Question4 & Question5 \\
\hline Question1 & &, $612\left(^{* *}\right)$ &, $689\left(^{* *}\right)$ &, $381\left(^{(*}\right)$ &, $652\left(^{(*}\right)$ \\
\hline Question2 & & &, $633\left(^{* *}\right)$ &, $369\left(^{* *}\right)$ &, $594\left(^{(*}\right)$ \\
\hline Question3 & & & &, $331\left(^{* *}\right)$ &, $672\left(^{(*}\right)$ \\
\hline Question4 & & & & &, $454\left(^{(* *}\right)$ \\
\hline Question5 & & & & & \\
\hline
\end{tabular}

** Correlation is significant at the 0.01 level (2-tailed).

Correlation values among the professional commitment items

\begin{tabular}{|l|l|l|l|l|l|}
\hline & Question1 & Question2 & Question3 & Question4 & Question5 \\
\hline Question1 & &, $660\left(^{* *}\right)$ &, $564\left(^{* *}\right)$ &, $\left.583^{* *}\right)$ &, $572(* *)$ \\
\hline Question2 & & &, $660\left(^{* *}\right)$ &, $672\left(^{* *}\right)$ &, $597\left(^{* *}\right)$ \\
\hline Question3 & & & &, $\left.822^{* *}\right)$ &, $753(* *)$ \\
\hline Question4 & & & & &, $769\left(^{* *}\right)$ \\
\hline Question5 & & & & & \\
\hline
\end{tabular}

** Correlation is significant at the 0.01 level (2-tailed).

Correlation values among the deliberate commitment items

\begin{tabular}{|l|l|l|l|l|l|}
\hline & Question1 & Question2 & Question3 & Question4 & Question5 \\
\hline Question1 & &, $530\left(^{* *}\right)$ &, $327\left(^{* *}\right)$ &, $264\left(^{(*}\right)$ &, $230\left(^{(*}\right)$ \\
\hline Question2 & & &, $584\left(^{* *}\right)$ &, $516\left(^{* *}\right)$ &, $425\left(^{(*}\right)$ \\
\hline Question3 & & & &, $628\left(^{* *}\right)$ &, $598\left(^{(*}\right)$ \\
\hline Question4 & & & & &, $713\left(^{(* *}\right)$ \\
\hline Question5 & & & & & \\
\hline
\end{tabular}

** Correlation is significant at the 0.01 level (2-tailed). 
Investigating the relationship between education and affective and professional commitment dimensions

\begin{tabular}{|c|c|c|}
\hline Chi-Square & 12,639 & 21,097 \\
\hline & AC & PC \\
\hline df & 2 & 2 \\
\hline Asymp. Sig. &, 002 &, 000 \\
\hline
\end{tabular}

a Kruskal Wallis Test

b Grouping variable: educational level

Examining the relationship between the age and each commitment dimension

\begin{tabular}{|c|c|c|c|c|c|}
\hline & AC & CC & NC & PC & DC \\
\hline Chi-Square & 29,749 & 25,580 & 18,792 & 15,845 & 3,892 \\
\hline df & 3 & 3 & 3 & 3 & 3 \\
\hline Asymp. Sig. &, 000 &, 000 &, 000 &, 001 &, 273 \\
\hline
\end{tabular}

a Kruskal Wallis Test

b Grouping variable: age group

Investigating the relationship between the wage and each commitment dimension

\begin{tabular}{|c|c|c|c|c|c|}
\hline & AC & CC & NC & PC & DC \\
\hline Chi-Square & 142,866 & 51,950 & 120,448 & 64,675 & 3,618 \\
\hline df & 2 & 2 & 2 & 2 & 2 \\
\hline Asymp. Sig. &, 000 &, 000 &, 000 &, 000 &, 164 \\
\hline
\end{tabular}

a Kruskal Wallis Test

b Grouping variable: wages

Examination the relationship between the existence or absence of foreign and each commitment dimension

\begin{tabular}{|c|c|c|c|c|c|}
\hline & AC & CC & NC & PC & DC \\
\hline Mann-Whitney U & 176995,000 & 180685,500 & 182612,500 & 189405,500 & 181795,500 \\
\hline Wilcoxon W & 217465,000 & 220588,500 & 222798,500 & 230733,500 & 1170916,500 \\
\hline Z & $-2,731$ & $-2,196$ & $-1,990$ & $-1,728$ & $-2,736$ \\
\hline $\begin{array}{c}\text { Asymp. Sig. (2-tai- } \\
\text { led) }\end{array}$ &, 006 &, 028 &, 047 &, 084 &, 006 \\
\hline
\end{tabular}

a Grouping variable: worked abroad

Investigating the relationship between the way of connection with the organization and each commitment dimension

\begin{tabular}{|c|c|c|c|c|c|}
\hline & AC & CC & NC & PC & DC \\
\hline Chi-Square & 13,212 & 15,190 & 9,551 & 8,671 & 2,063 \\
\hline df & 2 & 2 & 2 &, 013 & 2 \\
\hline Asymp. Sig. &, 001 &, 001 &, 008 & 356 \\
\hline
\end{tabular}

a Kruskal Wallis Test

b Grouping variable: first contact 